\title{
Original DocumentsCharter of Henry VII. To the Franciscan Friars at Greenwich, and an Inedited Seal of the Warden
}

Joseph Burtt Esq. \& Rev. James Graves M.A.

To cite this article: Joseph Burtt Esq. \& Rev. James Graves M.A. (1866) Original

DocumentsCharter of Henry VII. To the Franciscan Friars at Greenwich, and an Inedited Seal of the Warden, Archaeological Journal, 23:1, 54-59, DOI: 10.1080/00665983.1866.10851352

To link to this article: $h$ ttp://dx.doi.org/10.1080/00665983.1866.10851352

电 Published online: 11 Jul 2014.

Submit your article to this journal $\pi$

View related articles ¿ 


\section{Driginal 㑚ocuments.}

\section{CHARTER OF HENRY VII. TO THE FRANCISCAN FRIARS AT GREENWICH, AND AN INEDITED SEAL OF THE WARDEN.}

Tho Charter communicated by JOSEPE BURTT, Esq, Assistant Keeper of Public Records, and the Seal contributed by the Rev. JAMES GRAVES, M.A.

THE History of the Convent of Franciscan Friars at Greenwich, a house of royal foundation which seems to have been situated closely adjacent to the palace, long a favorite resort of the court and demolished by Charles II., has remained in much obscurity. Our attention has recently been called to the charter granted by Henry VII., not many months after his accession, and hitherto it is believed unpublished, having, so far as we are aware, been only cited briefly by Hasted, Lysons, and some other writers. ${ }^{1}$ It has been thought desirable to give at length a document that may be an acceptable contribution to the history of Kentish monasteries.

It appears that a religious house had been founded at Greenwich by Edward III. in 1376, for Friars Minorites, or Dominicans, according to Philipot; it was a cell to St. Peter's Abbey at Ghent, ${ }^{2}$ to which the manor of Greenwich appertained as part of the endowment of their cell at Lewisham; the manor of the place last-named had been given to the Abbey near Ghent by Eltrude, niece of King Alfred. ${ }^{3}$ Lysons lias observed, however, that he lad found no record of the foundation of a priory at Greenwich by Edward III., by the persuasion, as it had been alleged, of Sir John Norbury, his treasurer ; and he remarks that there is great reason to believe that no such house existed, but that it has been confounded with the Benedictine priory of Lewisham. ${ }^{4}$ Henry V., in the second year of his reign, suppressed the alien priories throughout England. ${ }^{5}$ It has been asserted by Weever and other writers, that the friars were at that time expelled from their house at Greenwich, and their possessions bestowed by the lking on the Carthusian priory which he had recently founded at Shene. ${ }^{6}$

In 1480, as stated in the Annals of the Order, Edward IV. conferred with the Vicar-general, William Bertholdi, being desirous to bring the Friars Observants, or Franciscans, into England. Edward granted them their first establishment at Greenwich, of which Sixtus IV., in the year

1 Hist. of Kent, vol. i. p. 550 ; Lysons' Environs, vol. iv. p. 464 .

2 Alien Priories, vol. ii. p. 138.

3 Dugdale, Mon. Angl., edit. Caley, t. vi. p. 987.

4 Lysons' Environs, ut supra. Sir John Norbury does not appear to have been treasurer until 1 Hen. $\nabla$.

5 Rot. Parl., vol, iv. p. 22 ; Alien Priories, vol. ii. p. 211.

6 Weever, Fun. Mon. p. 310; Dugd. Mon. Angl., vol. vi. p. 29 ; Lambarde, Peramb. of Kent, Greenwich, see s. $a$. 1416. 
before mentioned, sanctioned their acceptance. ${ }^{7}$ At this time, possibly, the convent may have become a Wardenship. ${ }^{8}$ According to the supposition of Hasted, Edward founded the convent near his palace through the persuasion of his sister, Margaret, Duchess of Burgundy. Lambarde, however, states that they "obtained by the means of Sir William Corbrige (as some thinke) a chauntrie with a little Chapel of the Holy Crosse, a place yet extant in the towne." 9

By the subjoined document, dated Dec. 14, 1 Hen. VII. (A.D. 1485) ${ }^{1}$ it appears that the king, - on the humble prayer of the Friars Observants of the Order of St. Francis in East Greenwich, and in consideration that his predecessor Edward IV. had, by license of the Pope for the foundation of a convent there, granted to the said Friars a certain parcel of land with buildings thereon, adjacent to the royal manor or palace, the said premises having been purchased by the ling for the erection of a church, conventual buildings, and other requisites of the house thus newly founded, and that the Friars, having taken possession and having laid the first stone with great solemnity, began to construct certain small buildings ("pauperculas domunculas") in honor of the Blessed Virgin, St. Francis, and All Saints, - granted and confirmed the said premises thus bestowed on the friars by Edward IV, and founded a convent to consist of a Warden and twelve brethren at the least. It is stated that Henry VII. subsequently rebuilt their convent from the foundation $:^{2}$ he was doubtless a great patron and promoter of the Order, which was indebted to that sovereign for not less than six convents in various parts of England.

The royal concessions to the Friars of Greenwich were ratified with no ordinary solemnity; the attesting witnesses of the new foundation were the archbishops-Thomas Bourchier, cardinal and primate of Engiand, and Thomas Rotheram, archbishop of York, at that time treasurer of England; he had been chancellor in the troublous times of Edward IV.;

7 In the library of Corpus Coll. Camb. MS. No. clsx, are to be found, No. 43, p. 72, "Testimonium fundationis domus fratrum minorum de observantia in villa de G. [Greenwich] Roff. dioc. per Edwardum IV. 2 Julii, 1482. Confirmatio cjusdem domus per episcopum Roff. virtrtte conmissionis a sede apostolica, eodem die ac anno." Catal, ed. Jac. Nasmith, p. 242.

$s$ Greenwich does not occur in the list of the Custodies and Wardenships of the Friturs Minor in England, amongst the niue convents of the Wardenship of London, as given by $\mathrm{Mr}$. Brewer in the "Monumenta Frauciscana," edited by him for the series of Chronicles and Memorials under direction of the Master of the Rolls, appendix, p. 579 .

- Perambulation of Kent, written in 1570 ; see the account of Greenwich, under the year 1480 , cited also by Weever, p. 339, Hasted, and other Kentish historians.

I In the edition of Dugdale's Monasticon by Caley, and in other notices of the convent, the date is erroneously gircn as
1486.

2 Dugdale, Mon. Ángl., ₹ol. vi. p. 1512, edit. Caley, citing Hist. of the English Franciscans, p. 216, where it is stated from the annals of the Order that Henry VII. built for the Franciscans three convents from the foundations-namely, Greenwich, Newark, and Richmond. Lambarde observes that " (as Polydore and Lilly say) King Henrie the Seventh builded for them that house adjoining to the Palaice which is there yet to be seene." Peramb. of Kent, under Greenwich. The convent stood, according to Hasted, adjoining to the west side of the palace, where the road, now known by the name of the Friars' Road, points out the situation. After the funal expulsion of the friars by Elizabeth in 1559, the priory buildings had been used as part of the palace; they were sold by the Parliamentary Commissioners in 1652 , and wele, probably, demolished when Charles II. began to rebuild the palace; the site is now occupied by part of Greenwich Hospital. 
also John Alcock, bishop of Worcester, lord chancellor, and Peter Courtenay, bishop of Exeter, keeper of the Privy Seal. With these eminent ecclesiastics are found as witnesses, Jasper Tudor, Duke of Bedford, uncle of Hemry VII., and John de la Pole, Duke of Suffolk; also John de Vere, Earl of Oxford, lord chamberlain, who had recently been restored to all his honors and possessions, and the Earl of Nottingham, earl marshal, Sir John Fitzwalter, steward of the household, Sir William Stanley, chamberlain, brother of Sir Thomas Stanley, created earl of Derby, the hero of Bosworth Field, and Sir Richard Croftes, treasurer of the royal household. It may deserve notice, as evidence of the faror and consideration of this sovereign to the Franciscans, that his letters patent should liave been thus attested by the great officers of the realm and principal officials of the court.

Of the subsequent history of the convent it may suffice to state, that Hemry VIII. was, in the early part of his reign, a zealous promoter of the Observants. At the request of the Friars of Greenwich he granted, in 1516 , a yearly pension of 1000 crowns to the brethren of that Order who kept the Holy Sepulchre at Jerusalem. ${ }^{3}$ His queen, Katherine of Arragon, showed also much favor to the Franciscans; one of the brethren of Greenwich, John Forrest, was her confessor. She was indeed herself, it is stated, of the third Order of St. Francis, and she was accustomed to rise at midnight to be present at matins and lauds, to the great edification of her subjects, in the chureh of the convent at Greenwich. ${ }^{4}$ They requited her favor by warmly espousing her cause in the affair of her divorce; and thus so greatly irritated the king that he suppressed the Order of Observants throughout England. The convent was dissolved August 11, 1534. On the accession of Mary, the Friars were reinstated in their possessions, and their convent was repaired at her cost, in remembrance, it is said, of their attachment to her mother. They were finally expelled by Elizabeth in 1559.5

No seal of the Convent of Greenwich has, so far as we are aware, been noticed. We are indebted to the Rev. James Graves, secretary of the Kilkenny and S.E. of Ireland Archæological Society, a zenlous antiquary, whose frequent courtesies we acknowledge with gratification, for an impression of the seal of the Warden, of which the matrix has, we fear, been unfortunately lost. Mr. Graves informs us that the impression, now in the collection of the Kilkenny Society, and from which the acconpanying woodcut has been executed, was given to him about 1849 by a Roman Catholic ecclesiastic, the late Rev. Dr. Nowlan, P. P. of Gowran; county Kilkenny, by whom it had been received, about forty years pre. viously, from some person connected with the Dominican Abbey of Killenny. It was stated that the impression in question was from the ancient seal of that monastery. The Dominicans, Mr. Graves observed, have become repossessed of the remains of their ancient house in Kilkenny, by lease from the Tynte family, the present owners of the site. Mr. Graves has in vain sought to trace where the matrix may now be found.

The seal, now first published, is of the pointed oval form; the device is the Assumption of the Blessed Virgin, who is seen supported by four angels;

3 Hist. of the English Franciscans, p. 218 , citing Wadding's Annals of the Order; see also Hist. Min. Proviu. Angl. Fratrum Minorum, p. 41.
4 Hist. Engl. Franciscans, ut supra.

5 Hasted, Hist. of Kent, and Iysons' Euvirons, vol. iv. p. 464. 
a radiant nimbus around her head; beneath is an escutcheon of the arms of France and England, quarterly, ensigned with the head of a cherub; the legend, in the bold capitals of the latter part of the fifteenth century, is (in extenso) as follows :- SIGILLVM - GARDIANI - GRVNWVCENSIS.

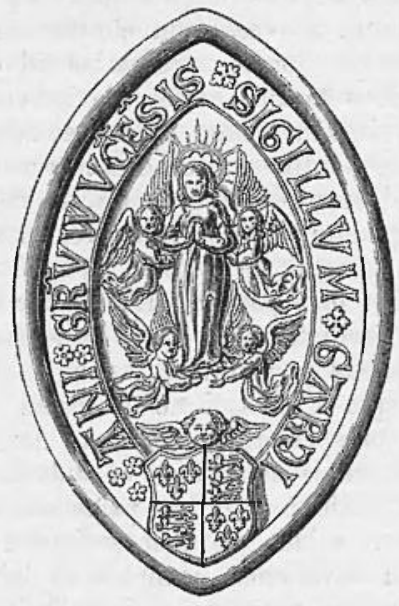

Seal of the Warden of the Franciscan Friars at Greenwich. From an impression preserved in the Museum of the Kilkenny Archreological Society. (Original size).

We may assign the seal to the period of the foundation of the Franciscan convent at Greenwich by Henry VII., in the first year of his reign. The lettering, it may be observed, is introduced upon a border or fillet that appears, in the impression, slightly raised, as seen in a few matrices of the period, above the field of the seal. It is possible that the letters may have been impressed on the metal by means of punches. Quatrefoils are used to separate the words of the legend.

We proceed to place before our readers the instrument preserved in the Charter Roll of the first year of Henry VII., in the Public Record Office. We are indebted to the oblioine assistance of $\mathrm{Mr}$. Burtt in bringing to light a valuable document, for which no place had been found amongst the voluminous additions compiled for the new edition of Dugdale's Monasticon.

\section{Rot. CART. 1 Henr. VII. No. 24. [A.D. 1485.]}

Rex archiepiscopis episcopis abbatibus prioribus ducibus comitibus baronibus justiciariis vice-comitibus prepositis ministris et omnibus ballivis et fidelibus suis salutem. Sciatis quod nos, ex humili supplicatione fratrum minorum de observantia ordinis Sancti Francisci in villa de Estgrenewiche in Comitatu Kancie commorantium, accepimus qualiter Edwardus nuper Rex Anglie quartus antecessor noster carissimus, ex suo mero motu et lonatione quibus ad eorum ordinem et familiam movebatur, a summo Pontifice petiit et obtinuit auctoritatem fundandi unam domum seu conventum pro usu et habitatione fratrum ordinis et familie ipsorum, sicut in bulla desuper impetrata plenius continetur. Demum dictus Edwardus nuper rex auctoritate sibi concessa uti volens, missis in dicto loco de Estgrenewiche Domino Jacobo Norwicensi et Domino Edmundo Roffensi epis- 
copis ab ipso Edwardo nuper Rege specialiter ad hoc deputatis, certam parcellam terre sue cum certis antiquis domibus desuper edificatis in dicta villa de Estgrenewiche, manerio nostro adtunc suo alias dicto placea regia contigue adjacentem, continentem in latitudine duodecim virgatas terre et in longitudine sexaginta et tres virgatas terre, per ipsum regem de suis propriis pecuniis emptam, ad ecclesiam cimitorium claustrum refectorium dormitorium ortos aliasque domos necessarias ad conventum dicti ordinis requisitas, certis fratribus ordinis et familie ipsorum tunc presentibus, et ceteris aliis fratribus ejusdem eciam ordinis et familie in dicto loco extunc futuris temporibus succedentibus, pro perpetuis usu et habitatione ipsorum predictorum fratrum minorum de observantia, de novo taliter construendas, dedit contulit et assignavit; ac eosdem fratres, posito primo lapide eorum futuri conventus cum solemnitate speciali in talibus fieri solita, in plenam possessionem et seisinam inde posuit. Et insuper hoc fratres predicti, sub spe et confidentia doni predicti mper Regis et augmentatione premissorum successione fienda, diversas pauperculas domunculas ad Dei et beatissime Virginis Marie Sanctique Francisci ac Omnium Sanctorum laudem et gloriam, pro salute et prosperitate totius regni Anglie imperpetuum deprecaturi, suis propriis laboribus sumptibus et sudoribus intentione premissa, devotione nonnullorum fidelium eis in hac parte assistente, de novo edificare inceperunt. Nos, non solum piam intentionem predicti nuper Regis bonasque dispositionem devotionem sumptus et labores eorundem fratrum die ac nocte in orationibus precibus et jejuniis ibidem Deo famulantiun, verum etiam qualiter inter cetera misericordie et pietatis opera divinorum celebratio a sacerdotibus verisque Dei vicariis canonice ministrata aliorum omnium maxime sit suprema; quamque meritorium fore credatur hujusmodi ministerium sustentare in quo miserime pecatorum anime ab eorum maculis purgate refrigerium consequuntur et veniam, ac fragiles in culparum voluptatibus deviantes adviam gratie reducuntur intime considerantes, de gratia nostra speciali ac ex certa scientia et mero motu nostris unum conventum sive domum Fratrum Minorum de observantia perpetuis futuris temporibus apud dictam villam de Estgrenewiche ad laudem et gloriam Dei, ut superius dictum est, ac beatissime Marie Virginis et Sancti Francisci et omnium sanctorum, de uno gardiano et duodecim fratribus ad minus, instituendum renovandum et continuandum juxta eorum regulam et statuta ac alias laudabiles consuetudines ordinatas et approbatas ac ordinandas et approbandas fundavimus ereximus creavimus et stabilivimus ac per presentes fundamus eregimus creamus et stabilimus. Et ut dicti fiatres et successores eorum pro bono statu nostro dum agimus in humanis ac pro anima nostra cum ab hac luce migraverimus imperpetuum deprecentur, dedimus ct concessimus ac per presentes damus et concedimus eisdem gardiano et conventui ac fratribus predictis ac successoribus fratribus suis ordinis et familie predictarum terras et tenementa superius specificata cum omnibus et singulis suis pertinentiis una cum domibus desuper edificatis; habenda et tenenda sibi et successoribus suis de nobis et heredibus nostris in liberam puram et perpetuam elemosinam imperpetuum absque aliqua inquisitione sive aliquibus inquisitionibus inde virtute brevis nostri de ad quod dampnum aut aliter fienda sive capienda quoquomodo, et absque aliquo fine seu feodo inde nobis aut heredibus nostris seu ad opus nostrum aliqualiter reddendis solvendis seu faciendis, statuto de terris et tenementis ad manum mortuam non ponendis aut eo quod expressa mentio de vero valore annuo seu aliquo alio valore terrarum et tenementorum predictorum 
in presentibus minime facta existit, vel aliquo alio statuto actu ordinatione sive provisione in contrarium factis editis ordinatis seu provisis, aut aliqua re causa vel materia in aliquo non obstantibus, jure speciali ecclesie parochialis cujuscumque semper salvo. Hiis testibus, Venerabilibus Patribus Thoma Cantuariensi totius Anglie Primate, consanguineo nostro carissimo, et Thoma Eboracensi Primate ac Thesaurario Anglie, archiepiscopis ; J. Wigorniensi Cancellario nostro Anglie, et P. Exoniensi Custode privati sigilli nostri, episcopis; Jasperi Bedefordie avunculo nostro carissimo, et Johanne Suffolchie, ducibus; Johanne Oxonie magno Camerario et Thoma Notynghamie Marescallo Anglie, Comitibus; ac dilectis et fidelibus nostris Jolianne Fitzwater senescallo, Willelmo Stanley Camerario, et Ricardo Croftes Thesaurario hospitii nostri, militibus, et aliis. Datum per manum nostram apud Westmonasterium xiiij. die Decembris.

Per breve de privato sigillo et de dato, \&c. et pro Deo quia pauperes. 